African Crop Science Journal by African Crop Science Society is licensed under a Creative Commons Attribution 3.0 Uganda License. Based on a work at www.ajol.info/ and www.bioline.org.br/cs DOI: https://dx.doi.org/10.4314/acsj.v27i2.14

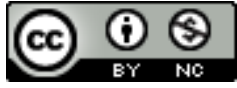

\title{
UNTAPPED POTENTIAL OF LIVINGSTONE POTATO, AN INDIGENOUS AND UNDERUTILISED ROOT CROP IN ZIMBABWE: A REVIEW
}

\author{
G.T. KUJEKE, U. MAZARURA, E. NGADZE, E. GASURA, J.T. RUGARE, A. MATIKITI \\ and R.T. MASEKESA \\ Department of Crop Science, Faculty of Agriculture, University of Zimbabwe, P. O. Box MP 167, \\ Mount Pleasant, Harare, Zimbabwe \\ Corresponding author: gtmkujeke@gmail.com
}

(Received 19 December 2018; accepted 20 May 2019)

\begin{abstract}
The Livingstone potato (Plectranthus esculentus), a tuberous root vegetable indigenous to Africa, remains a neglected and underutilised crop species (NUCS). Of late, there has been a shift in how the NUCS are viewed as consumers become increasingly aware of their nutritional and medicinal value. The objective of the review was to highlight research developments of the Livingstone potato and to identify existing research gaps in a quest to unlock the potential of this crop. Traditionally, the vegetable has been utilised for food, economic and medicinal benefits. However, recent research developments in Africa have demonstrated that the Livingstone potato is highly nutritious and can provide raw materials for the agro and pharmaceutical sectors. While these are notable developments, more needs to be done, especially in Zimbabwe where there is very little researched information on its production and utilisation. The economic impact could potentially be at household, farmer and national level through establishing strong value chains. This is important in order to increase awareness and promote the crop, whose production is on the decline. The diversity and nutritional value of the Livingstone potato needs to be evaluated in Zimbabwe, as a step towards crop improvement, which is key to improved productivity. Continuous production at a large scale will help preserve the germplasm and prevent the genetic erosion currently taking place. This review echoes previous calls for the government of Zimbabwe to take bold steps to support the NUCS, such as the Livingstone potato, at policy level and to fund programmes that deal with such crops.
\end{abstract}

Key Words: Medicinal, nutritious, Plectranthus esculentus

\section{RÉSUMÉ}

La pomme de terre Livingstone (Plectranthus esculentus), un légume-racine tubéreux indigène d'Afrique, reste une espèce qui est négligée et qu' on la n' utilize pas. Ces derniers temps, I y a eu le changement pour la façon de conciderer la pomme de terre Livingstone parceque les consommateurs deviennent de plus en plus conscients de leur valeur nutritionnelle et médicinale. L'objectif de la revue était de mettre en évidence les développements de la recherche sur la pomme de terre Livingstone et 
d'identifier les lacunes de la recherche existante dans le but de decouvrir le potentiel de cette culture. Traditionnellement, le légume a été utilisé pour de ressources alimentaires, économiques et médicinales. Toutefois, des travaux de recherche récents en Afrique ont montré que la pomme de terre Livingstone était très nutritive et pouvait fournir des matières premières aux secteurs agricoles et pharmaceutiques. Bien qu'il s'agisse d'évolutions notables, il reste encore beaucoup à faire, en particulier au Zimbabwe, où très peu d'informations ont été recueillies sur sa production et son utilisation. L'impact économique pourrait potentiellement être au niveau des ménages, des agriculteurs et de pays. Ceci est important pour sensibiliser et promouvoir la culture, dont la production est en déclin. La diversité et la valeur nutritionnelle de la pomme de terre Livingstone doivent être évaluées au Zimbabwe, dans la perspective d'une amélioration des cultures et essentiellement l'amélioration de la productivité. Une continuite de la production à grande échelle aidera de préserver le germoplasme et de prévenir l'érosion génétique en cours. Cette revue fait écho aux appels precedents et au gouvernement du Zimbabwe pour prendre des mesures audacieuses et soutenir la pomme de terre Livingstone en financant des programmes qui font les recherches sul la pomme de terre Livingstone.

Mots Clés: Médicinal, nutritif, Plectranthus esculentus

\section{INTRODUCTION}

The Livingstone potato (Plectranthus esculentus) is dicotyledonous and belongs to the Lamiaceace (Labiatae) family, which is also known as the mint family. With 236 genera and more than 7000 species, the Lamiaceae is the largest family among medicinal plants (Schippers, 2000; Paton, 2013). The species is widespread throughout the African continent, in the wild and under cultivation (Fox and Young, 1982; Codd, 1985; Dhliwayo, 2002; Allemann and Hammes, 2003). It is a perennial or woody herb that is aromatic, and differs from most members of the Lamiaceae family because it produces edible tuberous organs at the base of the stem (Kemas et al., 2013). Also known as the kaffir, wild, native or finger potato, the Livingstone potato is not a member of the Solanaceace family to which the common Irish potato (Solanum tuberosum) belongs (Greenway, 1944; Busch, 2015).

The Livingstone potato is one of the earliest African crops to be domesticated, and has now become a rarity after a long history of cultivation throughout the African continent (Schippers, 2000). It is regarded as a lost crop and as such, has been classified among the neglected and underutilised crop species (NUCS) (Williams, 2002; Eke-Okoro et al., 2008). The NUCS are defined as crops that have not been previously classified as major crops, have previously been under-researched, currently occupy low levels of utilisation; and are mainly confined to smallholder farming areas (Azam-Ali, 2010: Chivenge et al., 2015).

Globally, the Livingstone potato is considered a minor crop in terms of total production and commercial value; and its market is reportedly limited and has declined over the years, in favour of more 'modern' root crops such as yam (Dioscorea spp.), cassava (Manihot esculenta) and sweet potato (Ipomoea batatas) (Schippers, 2000). The production of such indigenous minor vegetable crops by the rural smallholder farmers has also led to the stigma associated with poor rural lifestyles, which regard them as low status foods; and as such, they have been neglected for a long time (Fusire, 2008). Despite this status, these indigenous vegetables are still valued in rural areas mainly because of the food security benefits, and in certain instances, economic benefits when surplus produce is sold (Dhliwayo, 2002).

Of late, there has been a shift in the perception of the NUCS and an increase in awareness of their nutritional and medicinal value (Ngugi et al., 2007). The importance of the NUCS is currently viewed in terms of potential for alleviating hunger directly, through increasing food production in challenging 
environments where major crops are severely limited; and through nutritional enhancement to diets focused on staples (Mayes et al., 2011). The Livingstone potato is one such crop that has been identified as a priority crop for research by the Southern and Eastern African Network for Underutilised Species (SEANUC) (Williams and Haq, 2002). There is a dearth of researched information on production and potential uses of the Livingstone potato in Zimbabwe. This review documents research efforts on the Livingstone potato, whose full potential has not been realised especially in Zimbabwe, and aims to identify the knowledge gap between recent technological advancements worldwide and the level of adoption so as to address any outstanding research questions with regards to its production.

Production status of Livingstone potato. The Livingstone potato is believed to have originally been selected from wild plants in either the Central African Republic or the Upper Niger Valley of the Hausaland region of Nigeria; and spread with the migration of people across Africa over the last 2000 years (Xaba et al., 2011). In Southern Africa, the Livingstone potato can be found in Malawi, Namibia, Swaziland, Angola, South Africa and Zimbabwe (Schippers, 2000). Its distribution points to its ability to thrive in almost all climates, as it is able to grow successfully in heavy humid as well as in hot dry climatic conditions (Allemann, 2002). It also grows in the wild, in dry woodlands, forest margins, rocky hillslopes and bushveld savanna (Xaba et al., 2011).

In Zimbabwe, the Livingstone potato is found in the wild as well as in cultivated lands. Its habitat in the wild consists of rocky woodlands, rocky sandy miombo woodlands, and Brachystegia woodlands. It has been sighted in the wild in Acturus, Christon Bank, Macheke, Matobo Mutorashanga and in certain rocky woody areas of Harare (Hyde et al., 2012). The major production areas in
Zimbabwe are located in Manicaland (Nyanga, Makoni and Mutasa) and Mashonaland East provinces, where individual farmers in a few villages in Seke, Hwedza and Chihota grow this crop (Dhliwayo, 2002).

Generally, there is paucity of literature on the improved agronomic practices for Livingstone potato (Allemann, 2002). Any reported production requirements for the Livingstone potato are generally those of a closely related crop, Hausa or coleus potato (Solenostemom rotundifolius), which is in the same Lamiaceae family (Tindall, 1983; Schippers, 2000). No research has been conducted in Zimbabwe in order to optimise the agronomy for improved productivity. This is the case for many underutilised crops such as the African yambean (Sphenostylis stenocarpa) and cocoyam (Colocasia spp.) (Williams and Haq, 2002; Mayes et al., 2011). Padulosi et al. (2013) also stated that the underutilised and neglected crops tend to be produced using traditional methods, mostly by women as is the case with the Livingstone potato in Zimbabwe (Dhliwayo, 2002: Kujeke et al., 2015).

The Livingstone potato produces seed which develops slowly and is heterogeneous (Schippers, 2000). However, Mwanja et al. (2015) reported that, while the Livingstone potato plant produced flowers at 158-215 days after planting, the flowers dried up without fruiting or seed-setting in all cultivars tested, probably because of the interplay of genetic and environmental factors. It is for this reason that cultivated forms of Livingstone potato are normally propagated vegetatively from small tubers. Further research is essential on the fruiting or seed setting as it impacts on the sexual propagation that leads to genetic variation, which could be beneficial with regards to improved varieties.

In Zimbabwe, Dhliwayo (2002) and Kujeke et al. (2015) highlighted that the crop was also propagated through tubers only, on raised beds in wetlands or vleis; while dryland cultivation is practiced in parts of the eastern highlands 
of the country. Production through rooted cuttings or suckers is reportedly possible (Tindall, 1983; Allemann, 2002); though not practiced in Zimbabwe. Production under dryland as is practiced in Malawi and areas near the Mozambican border (Dhliwayo, 2002). It is likely that most communities that practice wetland production on ridges in Zimbabwe, have not been fully exposed to the alternative method of dryland cultivation. Current laws in Zimbabwe prohibit wetland cultivation (Muzenda et al., 2002).

Production reportedly commences with field preparation in winter; whereby raised beds are constructed in the wetlands (Dhliwayo, 2002). Under dryland cultivation, clearing of vegetation is done followed by deep ploughing. The ideal soil types for the Livingstone potato under wetland and dryland production are not defined. Research carried out by Allemann and Hammes (2006) showed that tuberisation was affected by photoperiod. The specific genotype tested required exposure to four short day cycles. Since the photoperiod requirement is genotype specific, it is imperative to conduct research on the existing germplasm for improved productivity.

Allemann and Coertze (1996) reported that no serious pests and diseases attacked the Livingstone potato. However, wild pigs, rodents, nematodes and caterpillars were later found to be a problem and a few diseases which include soft rots and blights have been noted (Schippers, 2000: Kujeke et al., 2015). The occurrence of pests and diseases can be influenced by the prevailing environmental conditions, the susceptibility of germplasm, and the cultural practices during production. It is imperative that research be conducted to determine the effective methods to manage the specific pests and diseases that may impact on the production of the Livingstone potato.

The crop is reportedly ready for harvesting six to nine months after planting (Schippers, 2000). While bulk harvesting can be done, the crop can also be harvested piece meal as and when needed (Dhliwayo, 2002). Although the
Livingstone potato is characterised by lower yields, it will also produce harvestable yields where major food crops may fail (Safwan and Mohammed, 2016). Yields of Livingstone potato can be as low as two to six tonnes per hectare (Tindall, 1983), as opposed to on station yields. Schippers (2002) reported a yield potential of 13-25 $\mathrm{t} \mathrm{ha}^{-1}$ and up to $60 \mathrm{t}$ ha $^{-1}$ under optimal experimental conditions, using tissue culture produced plantlets in South Africa (Haq, 2004). The high yields obtained under experimental conditions clearly demonstrate a need for optimising the current traditional production methods in Zimbabwe. Information gathered from farmers during a survey by Kujeke et al. (2015) on the production status of the crop, revealed that production is currently on the decline in Zimbabwe due to various factors, mainly poor rainfall pattern over the years leading to a reduction in the area under wetlands. This, therefore, implores for further research into enhancing sustainable production under dryland conditions to prevent the genetic erosion of the crop due to climate change as wetlands continue to dry up.

Post-harvest handling. The harvested Livingstone potato tubers are highly perishable and as such, its production is faced with the challenge of high post-harvest losses. The harvested tubers are generally kept in cool areas and underground pits. A grass or leaf mulch is normally used for the open storage; ashes and grass are used for the underground storage. In either system of storage, tubers will normally keep for at least two months in Zimbabwe (Dhliwayo, 2002). Ezeocha and Ironkwe (2017) investigated the effect of different storage methods on the physiological and nutritional quality of the harvested tubers in Nigeria. Their work revealed that the best storage methods for the tubers are storing the tubers in pits with alternate layers of river sand, wood ash and wood shavings. These storage methods are appropriate for the smallholder farmers who produce the Livingstone potato. 
The Livingstone potato as a source of food. Livingstone potatoes are grown for their thickened roots or stems, which generally develop underground (Bradshaw, 2010). These plant organs have been found to be rich sources of carbohydrates and are commonly used as a dietary staple (Dansi, 2011). As a food source, the Livingstone potato can be used as a substitute for potato or sweet potato (Allemann, 2002), with its taste being described as slightly bitter than turnips (typical of immature tubers), to having a unique pleasant taste likened to turnips or parsnips, thus making it a delicious vegetable (Bryant, 1907; Fox and Young, 1982; Tredgold, 1986; Schippers, 2000). The tubers can also be boiled with beans or rice as a main meal, while the leaves of some varieties can be cooked as a vegetable (Demissie, 1991). The basic preparation of the tubers involves washing, scraping, boiling, frying or roasting. The tubers can be eaten on their own or added to stews, soups or other dishes (Tredgold, 1986; Burkill, 1995; Xaba et al., 2011). The taste and dry matter content probably determine which variety is cooked or eaten raw, or as a snack, as is the practice in Zimbabwe (Dhliwayo, 2002).

In West Africa, the Livingstone potato is a highly regarded vegetable root crop. For instance, in Cameroon, the boiled and very soft root vegetable has been used in the past as the first solid food given to young children during the transition from breastfeeding to more solid and starchy foods like yam or millet (Panicum miliaceum) (Schippers, 2000). In Nigeria, the crop is used for making special dishes during traditional ceremonies in commemoration of the ancestors (Schippers, 2000). In addition, the fresh tubers can also be dried for later use and prepared together with arrowroot or cocoyam for special occasions like funerals. The drying of the fresh tubers demonstrates the potential of the vegetable to be processed. A dish of mashed tuberous roots known in Zimbabwe as Chikone, is considered a traditional delicacy which is held in high esteem amongst the communities (Dhliwayo, 2002).

While the tuberous roots of the Livingstone potato form the primary product that is consumed especially in Zimbabwe (Dhliwayo, 2002: Kujeke et al., 2015), other parts of the plant have been proven to be edible. The choice of the plant part used for food is probably related to the genetic differences that exist within lines or varieties grown throughout the continent. In Kenya, in the Embu district, the Livingstone potato herbaceous stems are crushed using hand mills, soaked in water for about an hour, and the sieved liquid is used as a food additive to sweeten gruel (Allemann, 2002; Lukhoba et al., 2006). Demissie (1991) makes reference to the leaves being cooked and used as vegetables in Ethiopia; while in the Eastern Cape in South Africa, women communal farmers have been reported to grow selected lines of the Livingstone potato whose leaves can be cooked and eaten (Haq, 2004). The National Botanical Institute (1999) reported studies of herbarium samples to have revealed that the people of the Njoke district of Tanzania pickle the flowers of the Livingstone potato. In Zimbabwe, the tubers are the only edible part (Dhliwayo, 2002: Kujeke et al., 2015). It is, therefore, worth investigating whether the leaves can be consumed as genetic differences existing between lines may be the cause of the differences in the part plant eaten.

Food selection is governed by a number of sensory characteristics' such as taste' smell texture, colour (and other visual characteristics)' even sound (e.g. crunchiness), and physiologically perceived characteristics, like "fillingness" or "burningness" (Pelto et al., 1989). Underutilised vegetables can be used to prepare various value - added products, which can lead to improved consumption of such crops (Thillakawardane, 2009). Ukpabi et al. (2011) investigated the culinary and sensory characteristics of the Livingstone potato, and found the mealy boiled tubers and crispy salted 
French fries from the experimental tubers to be generally acceptable. There are limited culinary uses of this crop in Zimbabwe, and this might also seriously limit its production and demand (Dhliwayo, 2002). Good sensory and culinary characteristics are vital as they can enable researchers to fully exploit the Livingstone potato by exploring its value addition.

Nutritional benefits of Livingstone potato. Although uncommon in industrialised countries, malnutrition in children and other vulnerable groups remains a scourge in many developing countries, especially in sub Saharan Africa (Kramer and Allen, 2015). Consideration of indigenous vegetables which are usually rich in nutrients such as vitamin A and iron, that are often lacking in the diets of children and pregnant women, is imperative (Smith and Eyzaguirre, 2007). Of all the tuber vegetables, the Livingstone potato is regarded as highly nutritious, with high percentages of starch, essential amino acids and significant levels of calcium, iron and vitamin A; in addition to the useful trace elements and minerals (Xaba et al., 2011). The protein value is reportedly better than Irish potato; while the fat and total ash levels are higher compared to published values for other roots and tubers (Temple et al., 1991).

Allemann and Hammes (2003) compared the chemical composition of the Livingstone potato tubers from South Africa with corresponding values for taro, cassava, raw potato and two cultivars of raw sweet potato, Brondal (white flesh) and Mafutha (orange flesh); as well as Nigerian varieties of $P$. esculentus (Allemann and Hammes, 2003). They concluded that the Livingstone potato tubers can be a potential source of elements and compounds which are often deficient in the diet of rural South Africans, thus helping to alleviate malnutrition. Further, Ezeocha and Ironkwe (2017) carried out sensory evaluation and microbial stability checks of bread samples produced from wheat/Livingstone potato composite flour blends. Their work showed that the Livingstone potato flour could be used to substitute up to $15 \%$ of wheat flour in bread making, without adversely affecting the sensory and microbial stability of the bread. No research of this nature has been conducted using the Zimbabwe Livingstone potato landraces.

Characterisation of the nutrient composition of the Livingstone potato landraces indigenous to Zimbabwe has not been done. Knowledge of the nutritional composition would be of benefit to the communities that consume it. The addition of crops like the Livingstone potato to the diet adds diversity and diverse diets deliver nutrition and greater health with additional benefits for human productivity and livelihoods (Chivenge et al., 2015).

Genetic improvement. Underutilised root crops such as the Livingstone potato represent a pool of indigenous germplasm whose potential has not been fully unlocked by researchers. While they may never rise to the current status of exotic vegetables like potatoes and tomatoes globally, they are still worth investigating (National Research Council, 2006). The strongest argument for promoting these crop species is simply that, since people continue to use them, this constitutes a recognition of their value, sufficient to suggest that research priorities should be visited (Blench, 1997). This is the case in Zimbabwe, where communal farmers in the Mashonaland East and the Eastern Highlands provinces continue to produce the Livingstone potato for food and income.

From a breeding perspective, the genetic potential of a crop is determined by the combination of the genes it contains and their mutual interactions with the environment to produce the phenotype that could either be high yielding, resistant to pests, diseases or drought (Mayes et al., 2011). A prerequisite for any genetic improvement program is the knowledge of the extent of the genetic variation present between genotypes and the genetic 
distance between all closely related species with which hybrids could be produced (Beeching et al., 1993). Such information is currently unavailable for the Livingstone potato in Zimbabwe.

The assessment of the genetic diversity within and between plant populations is routinely performed using various techniques, such as morphological, biochemical characterisation and the use of molecular markers (Govindaraj et al., 2015). The genetic markers represent genetic differences between individual organisms or species. While they generally do not represent the target genes themselves, they act as 'signs' or 'flags' (Collard et al., 2005) which can be used to show the diversity between crop species. Without characterisation and evaluation the useful variation of these species remains poorly understood (Padulosi and Hoeschle-Zeledon, 2004). Kyesmu and Mantell (2002) provide the only documented molecular research for the Livingstone potato. Their work focused on DNA extraction methods for use in DNA finger printing of the Livingstone potato clones from Nigeria. No molecular studies have been conducted for the Livingstone potato landraces in Zimbabwe and as such, this review highlights this research gap.

The dearth of research information on the production of the Livingstone potato in Zimbabwe is exacerbated by the fact that little is known regarding the diversity of the germplasm, both in current production and in the wild. It is, therefore, important to collect and evaluate the germplasm, in order to provide researchers with resource material for crop improvement (Dhliwayo (2002). There is a possibility of improving yields to levels obtained in other countries like South Africa $\left(60 \mathrm{t} \mathrm{ha}^{-1}\right)$ if farmers use improved propagating material and improved agronomic practices (Burkill, 1995). The improvement of the Livingstone potato genetic resources is dependent on the continuous introduction of wild relatives, traditional varieties and the use of breeding techniques. These processes all require an assessment of diversity at some level, to select resistant and highly productive varieties (Mondini et al., 2009). This is yet to be done for the Livingstone potato germplasm in Zimbabwe.

Medicinal attributes of the Livingstone potato. The Lamiaceae or mint family to which the Livingstone potato belongs, is a very important medicinal family, mainly comprising of herbs or shrubs often with an aromatic smell (Raja, 2012). Other common members include most culinary herbs such as basil, mint, rosemary, sage, marjoram, thyme, lavandula, orthosiphon, ocimum, leucas, anisomeles, colebrookea, coleus, hyptis, oreganum, brunella, scutellaria, lamium, teucrium and perilla (Venkateshappa and Sreenath, 2013). Members of this family also possess oils, which are mostly present in leaves. However, oils can also be found in all above ground parts of the plants and are valuable in cosmetic, flavouring, fragrance, perfumery, pesticide, and pharmaceutical industries (Özkan, 2008). A review by Caroviæ-StanKo et al. (2016) clearly demonstrated that the species of this family possess antioxidant, antimicrobial, and anti-inflammatory properties.

With regards to the Livingstone potato, there are different schools of thought concerning its medicinal attributes. There is a general appreciation among the communal communities that the tuberous roots have medicinal properties, albeit being viewed as part of folk medicine. A survey done in 2001 in Zimbabwe by Dhliwayo (2002), reported that the Livingstone potato has been used to cure stomach aches, nausea, backache and problems associated with the female reproductive system. Allemann (2002) also reported similar medicinal uses. On the other hand, the National Research Council (2006) focuses on the Livingstone potato as being a one-product plant, which is a food and chooses to ignore the purported medicinal properties associated with the root vegetable. 
Perhaps the key issue is that the knowledge about the medicinal attributes of the NUCS such as the Livingstone potato remain hidden in indigenous knowledge systems, thus justifying the continued utilisation and preservation of certain crops (Chivenge et al., 2015). However, there is strong evidence that supports the medicinal attributes associated with the Livingstone potato (Lukhoba et al., 2006). The medicinal properties can play an important role in the lives of rural people who produce and consume them, particularly those in the remote parts of the developing countries, which have limited access to adequate health facilities (Safwan and Mohammed, 2016). Kyesmu (1994) recommended that a critical chemotaxonomic survey of the Livingstone potato plant should be undertaken, as the biochemical constituents could be of medicinal significance or have other uses. The onus for researchers is to extensively explore the medicinal attributes of the different landraces of the Livingstone potato, as a step in improving awareness and use since it is virtually untapped.

Burkill (1995) reported that a decoction can be taken for treating taenia (human tapeworm) in the Ubangi area of Democratic Republic of Congo (DRC); while a bolus of crushed leaf can be used as a suppository for oxyuris (human thread worm). Lukhoba et al. (2006) extensively reviewed the ethnobotanical uses of the Plectranthus genus to which the Livingstone potato belongs. Their review highlighted the following medicinal attributes: the treatment of a wide variety of digestive disorders, headache as well as cytotic and antitumor promoting activities (Morris and Msonthi, 1996; Mooi et al., 1999; Pakia et al., 2003). The growing interest in the substitution of synthetic food antioxidants with natural ones, in the maintenance of human health, has fostered increased research on the screening of plants for the identification of antioxidants. For example, Eleazu et al. (2010) stated that flour made from three varieties of the Livingstone potato was a natural source of antioxidants, and thus could be used in the treatment of ailments implicating free radicals.

Eleazu et al. (2014a) demonstrated the potential of Livingstone potato in the management of diabetes and hyperlipidemia. Their research showed the an-tidiabetic actions of Livingstone potato and its ability to ameliorate glomerular complications and liver hypertrophy in diabetics. Eleazu et al. (2014b) also investigated the effect of Livingstone potato incorporated feeds on diabetes and its complications in streptozotocin-induced diabetes in rats. The results of the study indicated the antidiabetic actions of Livingstone potato and its ability to amelio-rate glomerular complication and liver hypertrophy in diabetics.

The bioactive principles/natural products in Livingstone potato that justify its biological properties as used in folklore medicine were presented by Eleazu and Eleazu (2015). Their work showed that by isolating and identifying some compounds with biological activities in the Livingstone potato, new drugs could be developed from this plant in the future to treat various diseases. The research findings put to rest the speculations (Dhliwayo, 2002) that have existed with regards to the Livingstone potato's medicinal properties. These developments are very important and should be investigated further using the Livingstone potato landraces found in Zimbabwe. Positive results would have a huge impact as diabetes appears to be a growing problem in the African region where studies have shown that its prevalence in Zimbabwe has increased significantly over the past three decades (Mutowo et al., 2015).

Socio-economic impact. While orphan or minor crops like the Livingstone potato are typically not traded internationally, they can play an important role in regional food security (Mabhaudhi et al., 2017). In addition to the food security benefits, the Livingstone potato offers an economic advantage due to its 
uniqueness and suitability to environments in which it is grown using low inputs.

Historically, stems of the Livingstone potato plant are reported to have been used to make baskets by the Ngomi people in the district of KwaZulu-Natal in South Africa (National Botanical Institute, 2000). Further exploration of this practise could prove to be beneficial to communities that grow the vegetable, with regards to employment creation and income generation through the marketing of the products. In Nigeria, research by Okereke (2012) has shown that Livingstone potato meal can be used to reduce the cost of broiler feed, by including up to $30 \%$ of the Livingstone potato meal as a replacement for maize meal. This is significant in the sense that the savings from the reduced cost of broiler feed can be channelled to cater for other expenses required for improved livelihoods of those who produce broilers for consumption or for sale.

Industrial application. Emmambux and Taylor (2013) recommended that African starches should be investigated for non-food uses for applications such as adhesives, pharmaceutical excipients, sizing treatment, printing for paper manufacture, and warp sizing and fabric printing for textile industries. The starch quality of Livingstone potato has been shown to be similar to that of the starches found in cassava and sweet potato (Delpeuch et al., 1978). This clearly opens an avenue in Zimbabwe for further exploration into its processing for commercial starches.

Singh et al. (2003) reported that starch was one of the most widely used excipients in the food and pharmaceutical industries, where the starches were used as fillers, glidants, thickeners, binders, disintegrates as well as gelling, bulking, and water retention agents. Muazu et al. (2011) demonstrated that Livingstone potato starch compared well to maize starch BP (British Pharmacopoeia) in physicochemical properties; and could therefore, serve as an alternative to maize starch BP as an excipient in the pharmaceutical industries, especially in the manufacture of solid dosage forms. Ochekpe et al. (2013) evaluated the binding and disintegrating property of starch from tubers of the Livingstone potato in chloroquine phosphate tablets at a use level of five percent, and compared this with similar tablets formulated with maize or cassava starches as binder and disintegrant. Although maize starch gave the best results, the Livingstone potato starch fared better compared to the cassava starch, thus proving its potential which warrants further research, especially in Zimbabwe where there has been no research conducted.

Gender issues. In certain cases, underutilised crops like the Livingstone potato are associated with specific gender roles, with women being seen as particularly significant in the production of these crops (Mabhaudhi et al., 2016). Haq (2004) reported that in African rural communities, the women are empowered through producing these crops which they can process or sell directly to provide income for essentials such as school fees and health care thus, sustaining their livelihoods. In addition, they possess the valuable indigenous knowledge on the production and utilisation of these crops. This is clearly demonstrated in Zimbabwe with regards to the Livingstone potato, where the root vegetable is mainly produced by women in the communal areas and is primarily sold in nearby towns with the remainder being retained for household consumption (Dhliwayo, 2002: Kujeke et al., 2015). Schippers (2000) also places emphasis on the role of women in the production, processing and marketing (mainly retailing) of the Livingstone potato. In South Africa in the Eastern Cape, the farmers reportedly sell the fresh Livingstone potato tubers and cooked leaves in the local markets as well as to travellers (Haq, 2004).

Promoting the Livingstone potato in Zimbabwe. There is a need to develop strong value chains for the Livingstone potato in 
support of rural agricultural development and food security. This can be achieved through the research value chain, production, agroprocessing, and marketing (Mabhaudhi et al., 2017). Strategic interventions that help to make the Livingstone potato more commercially competitive by developing improved 'modern' varieties need to be taken (Padulosi et al., 2013). For example, biotechnology techniques have been employed to provide virus free planting material which consequently has helped to improve yields in sweet potato and cassava. Micro-propagation becomes an ideal choice to rapidly upscale the production and delivery of large quantities of superior cultivars and as such, offers a good distribution channel for improved yet underutilised crops (Dawson et al., 2009). Tissue culture is regarded as one of the most basic biotechnological tools available in sub-Saharan Africa and its vast and varied applications have significantly contributed to the safeguarding, improvement and distribution of vegetatively propagated orphan crops (Dubois, 2009). The same biotechnology techniques can also be investigated and applied for the Livingstone potato in South Africa where lack of improved planting material has also contributed to its decline in production (Dhliwayo, 2002: Kujeke et al., 2015).

Government policies should also focus on programmes that include increased awareness of the Livingstone potato. The University of Zimbabwe has also taken the initiative to research the NUCS (Brazier, 2016; Mapfumo, 2018) and research is currently ongoing on other NUCS which include cocoyam, amaranth, spider plant, sweet potato as well as the Livingstone potato. However, more needs to be done by involving stake holders in the industry so that innovations are rapidly disseminated and popularised. The government is urged to support such initiatives through funding this research area so that the full potential of the NUCS such as the Livingstone potato can be realised.

\section{ACKNOWLEDGEMENT}

The authors acknowledge the International Foundation for Science (IFS grant No: C/ 5431-1) and the Deutscher Akademischer Austausch Dienst (DAAD: A/1395622) In country scholarship for funding the research on the Livingstone potato in Zimbabwe.

\section{REFERENCES}

Allemann, J. and Coertze, A. 1996. Wild Potato (ARC-Roode plant Vegetable and Ornamental Plant Institute, Information Sheet A2 Indigenous Root Crops). Pretoria, South Africa: ARC-Roodeplaat Vegetable and Ornamental Plant Institute, Private Bag X, 293.

Allemann, J. 2002. Evaluation of Plectranthus esculentus $\mathrm{NE} \mathrm{Br}$ as a potential vegetable crop. PhD, University of Pretoria, South Africa.

Allemann, J. and Hammes, P. 2003. Chemical composition of South African Plectranthus esculentus tubers: Research in action. South African Journal of Science 99:127-129.

Allemann, J. and Hammes, P. 2006. Effect of photoperiod on tuberization in the Livingstone potato (Plectranthus esculentus NE Br. Lamiaceae). Field Crops Research 98:76-81.

Azam-Ali, S. 2010. Fitting underutilised crops within research-poor environments: Lessons and approaches. South African Journal of Plant and Soil 27(4):293-298.

Beeching, J.R., Marmey, P., Gavalda, M.-C., Noirot, M., Haysom, H.R., Hughes, M. A. and Charrier, A. 1993. An assessment of genetic diversity within a collection of cassava (Manihot esculenta Crantz) germplasm using molecular markers. Annals of Botany 72: 515-520.

Blench, R.M. 1997. Neglected species, livelihoods and biodiversity in difficult areas: how should the public sector respond. Natural Resource Perspectives Paper, 23. 
Bradshaw, J. 2010. Root and tuber crops. Handbook of Plant Breeding, 295. Springer, London.

Brazier, A. 2016. Underutilized crops championed at local university [Online]. Harare, Zimbabwe: Bio Innovation Zimbabwe. http://naturallyzimbabwean. com/2016/01/15/underutilized-cropschampioned-at-local-university/ Accessed 20 February 2016.

Bryant, A.T. 1907. A description of native foodstuffs and their preparation, Print for Natal Government. The Times Print. and Publishing Company, RSA.

Burkill, H. 1995. The useful plants of West Tropical Africa: Volume 3. Families JL. Kew: Royal Botanic Gardens, Kew xi, 857p.-. ISBN.

Busch, B. 2015. Plectranthus esculentus [Online]. Pretoria, South Africa: SA National Biodiversity Institute. Available: http:// pza.sanbi.org/plectranthus-esculentus [Accessed 2016].

Caroviæ-Stanko, K., Petek, M., Martina, G., Pintar, J., Bedekoviæ, D., Æustiæ, M. H. and Šatoviæ, Z. 2016. Medicinal plants of the family lamiaceaeas functional foods: A review. Czech Journal of Food Sciences 34: 377-390.

Chivenge, P., Mabhaudhi, T., Modi, A.T. and Mafongoya, P. 2015. The potential role of neglected and underutilised crop species as future crops under water scarce conditions in Sub-Saharan Africa. The International Journal of Environmental Research and Public Health 12:5685-5711.

Codd, L. 1985. Lamiaceae flora of Southern Africa 28 (4). Botanical Research Institute, Pretoria 79-102.

Collard, B., Jahufer, M., Brouwer, J. and Pang, E. 2005. An introduction to markers, quantitative trait loci (QTL) mapping and marker-assisted selection for crop improvement: the basic concepts. Euphytica, 142:169-196.

Dansi, A. 2011. Collecting vegetatively propagated crops (especially roots and tubers). Guarino, L., Ramanatha Rao, V. and Goldberg, E. (Eds.). Benin. pp.1-8. https://cropgenebank.sgrp.cgiar.org/ images/file/procedures/collecting2011/ Chapter21-2011.pdf Accessed 2 February 2017.

Dawson, I.K., Hedley, P.E., Guarino, L. and Jaenicke, H. 2009. Does biotechnology have a role in the promotion of underutilised crops? Food Policy 34:319-328.

Delpeuch, F., Favier, J.C. and Charbonniere, R. 1978. Characteristics of starches of tropical food plants. Annals of Agricultural Technology 27(4):809-826.

Demissie, A. 1991. Potentially valuable crop plants in a Vavilovian center of diversity: Ethiopia. International Conference on Crop Genetic Resources of Africa. Nairobi, Kenya. 26-30 September 1988.

Dhliwayo, P.D. 2002. Underexploited tuber crops in Zimbabwe: A study on the production of Livingstone potato (Plectranthus esculentus). Plant Genetic Resources Newsletter pp. 77-80.

Dubois, T. 2009. Importance of tissue culture for orphan crops. Inside this Issue 6:50.

Eke-Okoro, O., Olojede, A. and Nwadili, C. 2008. Studies on the optimum minisett sizes for rapid multiplication of rizga (Plectranthus esculentus), hausa potato (Solenosterum rotundifolium), and turmeric (Curcuma longa) in Nigeria. International Symposium on underutilized plants for food security. Nutrition, Income and Sustainable Development 806:169172.

Eleazu, C., Amadi, C. and Oti, E. 2010. Total antioxidant capacity, polyphenolic composition and cytotoxicity of three varieties of Livingstone potato (Rizga). Nigeria Agricultural Journal 41:39-45.

Eleazu, C. and Eleazu, K. 2015. Nutrient composition, antioxidant capacity and natural products in Livingstone potato (Plectranthus esculentus). Journal of Food Processing and Preservation 39:30503058. 
Eleazu, C., Eleazu, K., Chukwuma, S., Okoronkwo, J. and Emelike, C. 2014a. Effect of Livingstone potato (Plectranthus esculenthus $\mathrm{NE} \mathrm{Br}$ ) on hyperglycemia, antioxidant activity and lipid metabolism of streptozotocin induced diabetic rats. Toxicology Reports 1:674-681.

Eleazu, C.O., Eleazu, K.C., Ironkwe, A. and Iroaganachi, M.A. 2014b. Effect of Livingstone potato (Plectranthus esculenthus $\mathrm{NE} \mathrm{Br}$ ) on diabetes and its complications in streptozotocin induced diabetes in rats. Diabetes \& Metabolism Journal 38:366-374.

Emmambux, M.N. and Taylor, J. 2013. Morphology, physical, chemical, and functional properties of starches from cereals, legumes, and tubers cultivated in Africa: A review. Starch Stärke 65:715-729.

Ezeocha, C.V. and Ironkwe, A. G. 2017. Effect of storage methods and period on the physiological and nutrient components of Livingstone potato (Plectranthus esculentus) in Abia State, Nigeria. Open Agriculture 2:213-219.

Fox, F.W. and Norwood Young, M.E. 1982. Food from the veld; edible wild plants of Southern Africa. Delta Books, Craighall, Johannesburg, South Africa. 245pp.

Fusire, M. 2008. Seed production manual for Indigenous Vegetables: A guide for small scale farmers. Harare: Community Technology Development Trust (CTDT).

Govindaraj, M., Vetriventhan, M. and Srinivasan, M. 2015. Importance of genetic diversity assessment in crop plants and its recent advances: an overview of its analytical perspectives. Genetics Research International .

Greenway, P.J. 1944. Origins of some east African food plants: Part I. The East African Agricultural Journal 10:34-39.

Haq, N. 2004. Women reintroducing neglected crops. LEISA-LEUSDEN 20:28-29.

Hyde, M.A., Wursten, B., Ballings, P. and Palgrave, C. 2012. Flora of Zimbabwe.
Kemas, U., Nep, E. and Ochekpe, N. 2013. Comparative evaluation of the binding/ disintegrating properties of Plectranthus esculentus starch. World Journal of Pharmacy and Pharmaceutical Sciences 2: 906-920.

Kramer, C.V. and Allen, S. 2015. Malnutrition in developing countries. Paediatrics and Child Health 25:422-427.

Kujeke, G.T., Masekesa, R.T., Icishahayo, , D., Ngadze, E. and Mazarura, U. 2015. A survey of the production practices of Livingstone potato (Plectranthus esculentus), an indigenous and underutilized vegetable in Zimbabwe. Journal of Agriculture and Ecology Research International 4(4):175-187.

Kyesmu, P.M. 1994. Plectranthus esculentus N.E. BR. A minor tuber crop in dire need of rescue from extinction. Lamiales 3-5.

Lukhoba, C.W., Simmonds, M.S. and Paton, A.J. 2006. Plectranthus: A review of ethnobotanical uses. Journal of Ethnopharmacology 103:1-24.

Mabhaudhi, T., Chimonyo, V. and Modi, A. 2017. Status of underutilised crops in South Africa: opportunities for developing research capacity. Sustainability 9:1569.

Mabhaudhi, T., O'reilly, P., Walker, S. and Mwale, S. 2016. Opportunities for underutilised crops in Southern Africa's Post-2015 Development Agenda. Sustainability 8:302.

Mapfumo, T. 2018. The Livingstone potato. Ndeipi. Harare, Zimbabwe: Mike Garden.

Mayes, S., Massawe, F., Alderson, P., Roberts, J., Azam-Ali, S. and Hermann, M. 2011. The potential for underutilized crops to improve security of food production. Journal of Experimental Botany 63:10751079.

Mondini, L., Noorani, A. and Pagnotta, M.A. 2009. Assessing plant genetic diversity by molecular tools. Diversity 1:19-35.

Mooi, L.Y., Ali, A., Norhanom, A., Salleh, K.M., Murakami, A. and Koshimizu, K. 1999. Anti-tumor promoting activity of 
some Malaysian traditional vegetables (ulam). Natural Product Sciences 5: 33-38.

Morris, B. and Msonthi, J.D. 1996. Chewa medical botany: A study of herbalism in southern Malawi, LIT Verlag Münster.

Muazu, J., Musa, H., Isah, A.B., Bhatia, P.G. and Tom, G.M. 2011. Extraction and characterization of kaffir potato starch: A potential source of pharmaceutical raw material. Journal of Natural Product and Plant Resources 1(2):41-49.

Mutowo, M., Gowda, U., Mangwiro, J. C., Lorgelly, P., Owen, A. and Renzaho, A. 2015. Prevalence of diabetes in Zimbabwe: A systematic review with meta-analysis. International Journal of Public Health 60: $1-11$.

Muzenda, S., Machingaidze, A.B., Riches, C., Ellis-Jones, J. and Chivinge, O.A. 2002. Weed management options for seasonal wetlands (VLEIS) in semi-arid areas of masvingo province, Zimbabwe. Proceedings of the Seventh Eastern and Southern Africa Regional Maize Conference, Nairobi, Kenya. pp. 113-119.

Mwanja, Y., Goler, E. and Gugu, F. 2015. Flowering and seed-setting studies in Livingstone potato (Plectranthus esculentus NE BR.) in Jos-Plateau, Nigeria. International Journal of Plant Breeding and Genetics 9:275-279.

National Research Council, 2006. Lost crops of Africa: Volume II: Vegetables (Vol. 2). National Academies Press. Washington D.C., USA. pp. 269-285.

Ngugi, I. K., Gitau, R. and Nyoro, J. 2007. Access to high value markets by smallholder farmers of African indigenous vegetables in Kenya. Regoverning Markets Innovative Practice Series, IIED, London.

Ochekpe, N. A., Kemas, U. C. and Nep, E. I. 2013. Chemical modifications and their effects on binding/disintegrating properties of Plectranthus esculentus starch in chloroquine phosphate tablets. American Journal of PharmTech Research 3(3): 867 877.
Okereke, C. 2012. Growth performance of finisher broilers on Livingstone-potato (Plectranthus esculentus) Tubers Meal. Pakistan Journal of Nutrition 11: 411-413.

Özkan, M. 2008. Glandular and eglandular hairs of Salvia recognita Fisch. \& Mey. (Lamiaceae) in Turkey. Bangladesh Journal of Botany 37:93-95.

Padulosi, S. and Hoeschle-Zeledon, I. 2004. Underutilized plant species: what are they? LEISA-LEUSDEN 20:5-6.

Padulosi, S., Thompson, J. and Rudebjer, P. 2013. Fighting poverty, hunger and malnutrition with neglected and underutilized species: Needs, challenges and the way forward. Bioversity International.

Pakia, M., Cooke, J. and Van Staden, J. 2003. The ethnobotany of the Midzichenda tribes of the coastal forest areas in Kenya: 2. Medicinal plant uses. South African Journal of Botany 69:382-395.

Paton, A. 2013. Lamiaceae Flora Zambesiaca 8 (8). Includes a Picture 275-278.

Pelto, G., Pelto, P. and Messer, E. 1989. Research methods in nutritional anthropology. Food and Nutrition Bulletin. Supplement (UNU).

Raja, R.R. 2012. Medicinally potential plants of Labiatae (Lamiaceae) family: An overview. Research Journal of Medicinal Plant 6:203-213.

Safwan, I. and Mohammed, U. 2016. Review on the nutritional value, cultivation and utilization potential of some minor and under-utilized indigenous root and tuber crops in Nigeria. International Journal of Advanced Research 4:1298-1303.

Schippers, R.R. 2000. African indigenous vegetables: An overview of the cultivated species. University of Greenwich, Natural Resources Institute: London, UK. pp. 8183.

Singh, N., Singh, J., Kaur, L., Sodhi, N. S. and Gill, B. S. 2003. Morphological, thermal and rheological properties of starches from different botanical sources. Food Chemistry 81:219-231. 
Smith, I.F. and Eyzaguirre, P. 2007. African leafy vegetables: Their role in the World Health Organization's global fruit and vegetables. African Journal of Food, Agriculture, Nutrition and Development 7(3):1-17.

Thillakawardane, T. 2009. Market opportunities for value-added products of underutilized fruits and vegetables. Acta Horticulturae 806(2):465-472.

Tindall, H.D. 1983. Vegetables in the tropics. Macmillan Press Ltd London. pp. 241-242.

Tredgold, M.H. 1986. Food plants of Zimbabwe: With old and new ways of preparation, Mambo Press. Gweru. 103pp. Ukpabi, U.J., Oti, E. and Ogbogu, N.J. 2011. Culinary and sensory characteristics of Hausa potato (Solenostemon rotundifolius) and Livingstone potato (Plectranthus esculentus) tubers in Nigeria. Journal of Stored Products and Postharvest Research 2:301-304.
Venkateshappa, S. and Sreenath, K. 2013. Potential medicinal plants of Lamiaceae. American International Journal of Research in Formal, Applied and Natural Sciences 1:82-87.

Williams, J.T. and Haq, N. 2002. Global research on underutilized crops: An assessment of current activities and proposals for enhanced cooperation. International Plant Genetic Resources Institute. International Centre for Underutilised Crops. Southampton, UK. 19pp.

Williams, J.T. 2002. Global research on underutilized crops: An assessment of current activities and proposals for enhanced cooperation, Bioversity International.

Xaba, P. and Croeser, P. 2011. Wild Potato. Veld \& Flora 97(4):180-181. 